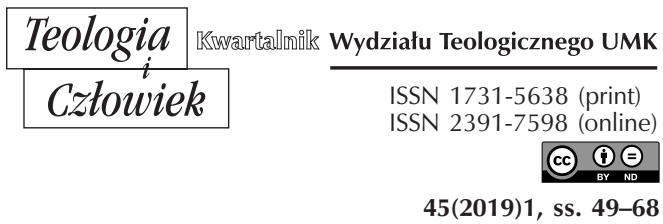

KS. ANDRZEJ ANDERWALD

WYDZIAL TEOLOGICZNY UNIWERSYTETU OPOLSKIEGO

ANDERW@UNI.OPOLE.PL

ORCID: 0000-0001-5932-9845

\title{
W POSZUKIWANIU NOWEJ IDEI POSTĘPU TECHNICZNEGO PERSPEKTYWA TEOLOGICZNA
}

DOI: http://dx.doi.org/10.12775/TiCz.2019.003

\begin{abstract}
Streszczenie. Technika jest dziś wielkością, która określa wszystko bądź prawie wszystko w otaczającej nas rzeczywistości. Nie ma sfery życia, która nie pozostawałby pod jej wpływem, czy też, w której można by ją uznać za zbyteczną. W perspektywie chrześcijańskiej teologii stworzenia można powiedzieć, iż człowiek poprzez postęp techniczny uczynił sobie ziemię poddaną, co więcej, z jego pomocą znacząco zmienił oblicze ziemi. Ocena postępu technicznego i jego skutków nie jest łatwa i jednoznaczna. W ocenie etycznej pojawiają się coraz częściej opinie, że postęp może prowadzić zarówno do dobra, jak również do zła. Zamierzeniem podjętych rozważań jest próba poszukiwania nowej idei postępu technicznego, która sprzyjałaby budowaniu integralnej wizji rzeczywistości. Podstawą dla rozważań jest nauczenie ostatnich papieży zawarte w encyklikach Redemptor hominis (1978) - Jana Pawła II, Caritas in veritate (2010) - Benedykta XVI i Laudato si' (2015) - Franciszka.
\end{abstract}

Słowa kluczowe: teologia chrześcijańska; postęp techniczny; integralna wizja rzeczywistości.

Abstract. In Search of a New Idea of Technical Progress. Theological Perspective. A technique is now a greatness that defines everything or almost everything in the reality that surrounds us. There is no space of life that would not be influenced by it, or in which it could be considered as a superfluous. In the perspective of Christian theology 
of creation, it can be said that a man has made the earth subdue to the technical progress, and what is more, with his help he has significantly changed the face of the earth. The assessment of technical progress and its effects is not easy and unambiguous. In ethical evaluation appear opinions that progress can lead to both good and bad. The propose of the considerations is searching for a new idea of technical progress that would foster an integral vision of reality. The basis for reflections is the teaching of the three most recent Pontificates contained in the Encyclicals: Redemptor hominis (1978) of John Paul II, Caritas in veritate (2010) of Benedict XVI and Laudato si' (2015) of Francis.

Key words: Christian theology; technical progress; integral vision of reality.

„Jestem przekonany - stwierdził Prezydent RP Andrzej Duda w wystąpieniu otwierającym Szczyt Klimatyczny COP24 w Katowicach (2-12 grudnia 2018) - że postęp technologiczny, który ma swój wpływ na zanieczyszczanie naszej planety, a przez to na zmiany klimatyczne, może jednocześnie przyczynić się do jej oczyszczenia, poprawiając warunki życia ludzi na całym świecie i dając możliwość zrównoważonego rozwoju" ${ }^{\prime}$. Wydaje się, że dostrzeżenie również pozytywnej funkcji postępu technicznego wiąże się równocześnie $\mathrm{z}$ wyzwaniem do humanistycznej refleksji, nie tyle nad znaczeniem wytworów nauki i techniki w dziejach ludzkości, co nad samą ideą postępu technicznego. Rozważania tego typu zapoczątkowane już na płaszczyźnie filozofii, ze szczególnym uwzględnieniem perspektywy etycznej, stopniowo doprowadziły do wyodrębnienia się z ogólnej refleksji filozoficznej nowej dyscypliny szczegółowej - filozofii techniki². Obecnie również coraz wyraźniej zaczyna się kształtować jeszcze jedna nowa perspektywa badawcza - teologiczna. Wprawdzie w obszarze języka polskiego nie zadomowił się jeszcze termin „teologia techniki”, to termin zaczyna się być używany w odniesieniu do tego typu

${ }^{1}$ A. Duda, Wystapienie podczas otwarcia Szczytu Klimatycznego oraz Szczytu Liderów COP24 (Katowice 3.12.2018) http://www.prezydent.pl/aktualnosci/wypowiedziprezydenta-rp/wystapienia/art,589,wystapienie-prezydenta-rp-podczas-uroczystego-otwarcia-szczytu-klimatycznego-oraz-szczytu-liderow-cop24.html [dostęp: 6.12.2018].

2 Zob. A. Nordmann, Technikphilosophie zur Einführung, Hamburg 2015; A. Bogner (red.), Ethisierung der Technik - Technisierung der Ethik. Der Ethik-Boom im Lichte der Wissenschafts- und Technikforschung, Baden - Baden 2013; B. Irrgang, Philosophie der Technik, Darmstadt 2008. 
rozważań w obszarze języka angielskiego "The Theology of Technology”" i niemieckiego „Theologie der Technik”"

Inspiracje do uwzględnienia, obok filozoficznej również perspektywy teologicznej, znajdujemy w nauczaniu ostatnich papieży: św. Jana Pawła II (1920-2005) i Benedykta XVI (ur. 1927) i Franciszka (ur. 1936). Wprawdzie jak dotąd nie został wydany osobny dokument kościelny explicite odnoszący się do postępu technicznego, to jednak w nauczaniu papieży nie brak bezpośrednich odniesień do zagadnień związanych z rozwojem technicznym. Obok okazjonalnych wypowiedzi można wyraźnie wskazać na trzy dokumenty w randze encyklik, w których nawiązują do zagadnień zwianych z postępem technicznym: Redemptor hominis (1978) Jana Pawła II, Caritas in veritate (2010) - Benedykta XVI i Laudato si' (2015) - papieża Franciszka.

Zamierzeniem podjętych rozważań jest próba poszukiwania nowej idei postępu technicznego, która sprzyjałaby budowaniu integralnej wizji rzeczywistości respektującej najwyższą wartość osoby ludzkiej. Struktura rozważań nawiązuje do tzw. trzech kroków opisanych w encyklice $\mathrm{Ma}$ ter et Magistra (1961) przez papieża Jana XXIII (1881-1963). Najpierw, bowiem trzeba „dojrzeć prawdziwy stan rzeczy; potem należy sumiennie ocenić według tych zasad; i wreszcie trzeba stwierdzić, co można i należy uczynić, by zastosować przekazane normy zgodnie z tradycją miejsca i czasu. Te trzy kroki dadzą się opisać trzema słowami: patrzenie, ocenianie, działanie" (nr 236). Dlatego w toku rozważań zostanie najpierw dokonana charakterystyka postępu technicznego (1); następnie próba jego oceny (2) oraz przedstawiony postulat integralnego ujmowania rzeczywistości (3).

3 Zob. A. Padgett, God Versus Technology? Science, secularity, and the Theology of Technology, „Zygon” 3 (2005), s. 577-584.

${ }^{4}$ Zob. H.D. Mutschler, Die Gottmaschine. Das Schicksal Gottes im Zeitalter der Technik, Augsburg 1998, s. 243-248; S. Schleissing, Laien, Experten, Propheten: Zur Rolle der Theologen in Technikdiskursen, w: Technik und Lebenswirklichkeit: Philosophische und theologische Deutungen der Technik im Zeitalter der Moderne, red. A.-M. Richter, Ch. Schwarke, Stuttgart 2014, s. 203-216. 


\section{POSTĘP TECHNICZNY}

Współcześnie technika i związany z nią nierozerwalnie postęp techniczny, jak również cywilizacja naukowo-techniczna, są to wielkości, które określają wszystko bądź prawie wszystko w otaczającej nas rzeczywistości. Wytwory techniki są powszechnie obecne we wszystkich obszarach naszego życia i wszystkich miejscach globu. Nie ma sfery życia (i to począwszy od życia gospodarczego, a skończywszy na domowym), która nie pozostawałby pod jej wpływem, czy też, w której można by ją uznać za zbyteczną. Pojęcie nowoczesnej techniki i postępu technicznego zostało ukształtowane pod wpływem rewolucji naukowo-technicznej przełomu XIX i XX wieku. Jest to okres, w którym dochodzi do coraz ściślejszego oparcia techniki na naukach matematyczno-przyrodniczych. To ścisłe powiązanie sprzyja tworzeniu nowych jakościowo wynalazków, które poszerzają znacznie dostępność dobrobytu i w dalszej konsekwencji oddziaływają na zmiany struktur społecznych. Nowoczesna technika nie jest tylko narzędziem, czy umiejętnością, jak zdaje się sugerować etymologia tego słowa (z gr. techne - sztuka, umiejętność), lecz cechuję się pewnym dynamizmem, który wyraża się w dokonującym się nieprzerwanie, metodycznie zaplanowanym postępie technicznym. Można powiedzieć, że współczesna techne nie tylko zna swoje twory i je tworzy względnie przetwarza, ale również, jak zauważa Colin Miller, posiada nad nimi władzę i może nimi manipulowaćs. Postęp techniczny dąży dziś do tego, aby nie tylko poznawać czy wpływać na przyszłość, ale wręcz przy pomocy właściwej mu metodologii ją projektować6. Taki sposób postępowania prowadzi do ukształtowania się swoistego paradygmatu technologicznego, ukierunkowanego m.in. na prognozowanie przyszłości. Paradygmat ten stanowi wyzwanie dla chrześcijańskiej wizji rzeczywistości, w tym szczególnie antropologii chrześcijańskiej. Stąd i wzrastające zainteresowanie refleksją teologiczną nad postępem technicznym i jego skutkami ze strony Kościoła.

${ }^{5}$ C. Miller, Technocracy and Tradition, „Communio. International Catholic Review" 44 (2017) 4, s. 737.

6 Tamże, s. 743. 
Wprawdzie Jan Paweł II w pierwszej encyklice Redemptor hominis nie dokonuje ogólnej charakterystyki postępu, ale formułowane przez niego zastrzeżenia, wątpliwości wobec zachwiania proporcji pomiędzy rozwojem techniki a rozwojem duchowym człowieka, wskazują pośrednio na pewne przymioty postępu technicznego: „Czy wszystkie dotychczasowe i dalsze osiągnięcia techniki idą $\mathrm{w}$ parze $\mathrm{z}$ postępem etyki i $\mathrm{z}$ duchowym postępem człowieka? Czy człowiek, jako człowiek w ich kontekście również rozwija się i postępuje naprzód, czy też cofa się i degraduje w swym człowieczeństwie?"7. W stymulowanym przez rozwój techniczno-produkcyjny podejściu do rzeczywistości papież dostrzega jego jednowymiarowość, która determinuje rozwój ludzkiej kultury. Ponadto dokonujący się postęp sprzyja poszerzaniu obszarów panowania techniki, zdobywania władzy i związanego z nią autorytetu. Dlatego papież wyraźnie postuluje, aby w trosce o człowieka uczynić postęp przedmiotem refleksji teologicznej, której uzasadnienie „Kościół znajduje w samym Jezusie Chrystusie [...] w Nim też stale pragnie ją rozwijać, odczytując sytuację człowieka w świecie współczesnym wedle najważniejszych znaków naszego czasu"8.

Jeszcze więcej uwagi zagadnieniom postępu technicznego, jego skutkom poświęca papież Benedykt XVI. W encyklice Caritas in veritate, dedykuje tym kwestiom osobny rozdział zatytułowany: Rozwój narodów a technika ${ }^{9}$. Właściwy dla człowieka rozwój wpisany w jego naturę jest „ściśle związany - jak zauważa papież - z postępem technologicznym, $\mathrm{z}$ jego zadziwiającymi zastosowaniami w dziedzinie biologicznej. Technika jest działalnością głęboko ludzką, związaną z autonomią i wolnością człowieka. W technice wyraża się i potwierdza panowanie ducha nad materią" ${ }^{10}$. Jeśli jednak człowiek w refleksji nas rozwojem technicznym szuka tylko odpowiedzi na pytania jak dochodzi do postępu czy też jak przebiega jego ewolucja w historii, a nie stawia pytania, dlaczego w ogóle dokonuje się postęp, to takie podejście poznawcze może prowadzić do przekonania o jego samowystarczalności. Takie ujęcie prowadzi do traktowania rozwoju technicznego czy samej techniki jako wielkości

\footnotetext{
${ }^{7}$ Jan Paweł II, Encyklika Redemptor hominis, nr 15 (dalej jako RH).

8 Tamże.

9 Benedykt XVI, Encyklika Caritas in veritate, nr 68-77 (dalej jako CiV).

10 Tamże, nr 69.
} 
autonomicznych, które nie muszą podlegać ocenie z zewnątrz. Ponadto idea samowystarczalności techniki, nie tylko sprzyja jej absolutyzacji, lecz ma również wpływ na kształtowanie się mentalności technicystycznej. Mentalność taka „staje się tak mocna - naucza papież - że dochodzi do utożsamienia prawdy z tym, co możliwe do urzeczywistnienia. Ale kiedy jedynym kryterium prawdy jest skuteczność i użyteczność, rozwój zostaje automatycznie zanegowany"11. Wpływa ona również na upowszechnianie i wzrost materialistycznej i mechanicystycznej koncepcji życia ludzkiego ${ }^{12}$, w której nie ma miejsca dla Bożego działania.

Z tą postępującą «ekspansją» nauk ścisłych, a zwłaszcza ich zdolnością podporządkowania sobie natury przez technikę, - jak zauważa Benedykt XVI - jest czasem związane równoczesne „ustępowanie” filozofii, religii, a nawet wiary chrześcijańskiej. Niektórzy uważają wręcz, że postęp nowoczesnej nauki i technologii jest jedną z głównych przyczyn laicyzacji i materializmu: po cóż mielibyśmy prosić Boga o panowanie nad zjawiskami przyrody, skoro nauka wykazała, że sama jest do tego zdolna? ${ }^{13}$.

Z kolei papież Franciszek, jeszcze wyraźniej niż jego poprzednicy, postęp techniczny wiąże $\mathrm{z}$ panowaniem człowieka nad przyrodą oraz człowieka nad człowiekiem, względnie jednych społeczności nad drugimi. Taki sposób postępowania prowadzi do ukształtowania się swoistego paradygmatu, w którym „wyróżnia się koncepcja podmiotu, który stopniowo, $\mathrm{w}$ procesie logiczno-racjonalnym, pojmuje, a zatem posiada rzecz, która znajduje się na zewnątrz. Taki podmiot wyraża się poprzez ustanowienie metody naukowej wraz z powiązanym $\mathrm{z}$ nią eksperymentowaniem, które jest już wyraźnie techniką posiadania, dominacji i przekształcania"14. Taka sytuacja uniemożliwia powstaniu charakterystycznej w przeszłości relacji człowieka do przyrody, a jedynie dochodzi do wykorzystania danej rzeczy, czy samych dóbr natury. Współczesny postęp techniczny

11 Tamże, nr 70.

12 Tamże, nr 75.

${ }^{13}$ Benedykt XVI, Boża Opatrzność a działalność człowieka. Przemówienie do uczestników sesji plenarnej Papieskiej Akademii Nauk (6.11.2006). https://opoka.org.pl/ biblioteka/W/WP/benedykt_xvi/przemowienia/pan_opatrznosc_06112006.html [dostęp: 10.11.2018].

${ }_{14}$ Franciszek, Encyklika Laudato si', nr 106 (dalej jako LS). 
dąży do nieograniczonego wzrostu, który zakłada „fałszywe przekonanie o nieskończonej dostępności dóbr naszej planety, co prowadzi do ich «wyciskania» aż do ostatecznych granic, a nawet ponad granice"15. Ukierunkowana na posiadanie technika nie zadawala się tylko panowaniem nad przyrodą, ale oddziałuje również na wymiar społeczny, gospodarczy, czy polityczny ${ }^{16}$. To, co się liczy, to zysk, bez względu na skutki w postaci zniszczenia przyrody czy zubożenia całych społeczeństw z powodu ich wykluczenia ${ }^{17}$. Dlatego wytwory techniki nie są neutralne, gdyż mają one wpływ na styl życia, jak również nierzadko, zgodnie z interesami określonych grup władzy, wyznaczają kierunki rozwoju poszczególnych społeczeństw ${ }^{18}$. Stosowania $\mathrm{w}$ technice metodologia dąży do zapanowania nad całą rzeczywistością. „W istocie - jak zauważa Franciszek - technika dąży do tego, aby nic nie pozostawało poza jej żelazną logika ${ }^{19}$.' Opisując w ten sposób zakres rzeczywistości, który pragnie objąć swym działaniem technika, akcentuje on jej dążenia do objęcia całej rzeczywistości. W nawiązaniu do myśli Romano Guardiniego stwierdza wprost, że technika jest dziś formą życia ${ }^{20}$. Technika, postęp techniczny stanowią dziś składowe paradygmatu technokratycznego, który głosi nieprzerwane udoskonalanie warunków życia, co daje możliwość urzeczywistnienia szczęścia coraz to większej liczby ludzi. Tak rozumiany postęp technologiczny budzi coraz większe oczekiwania i rozbudza quasi religijne nadzieje, iż jest on w stanie pokonać i zapanować w ostateczności nad wszystkimi problemami związanymi ze środowiskiem ${ }^{21}$. Pogląd taki prowadzi nierzadko do gloryfikacji techniki i absolutyzacji jej logiki, czy wręcz, jak zauważa Hans Dieter Mutschler, deifikacji ${ }^{22}$.

15 Tamże.

16 Tamże, nr 107, 109.

17 Por. Th. Wieland, „Laudato Si” praktisch, „Herder Korrespondenz” 11 (2016), s. 49.

18 Por. J. Bremer, Encyklika Laudato się - ekologia integralna podstawowym elementem katolickiej nauki społecznej, w: Kościół i nauka w obliczu ekologicznych wyzwań, red. J. Poznański, S. Jaromi, Kraków 2016, s. 41-42.

19 LS, nr 108.

20 Tamże, nr 203.

21 Tamże, nr 109.

${ }^{22}$ Por. H.D. Mutschler, Technik als Religionsersatz, „Scheidewege. Jahresschrift für skeptisches Denken” 28 (1999), s. 42-54. 
Jak dalece absolutystyczne roszczenia wynikające z stosowania paradygmatu technologicznego są rzeczywiście pomocne w interpretacji całej rzeczywistości? Dokonana przez papieży ogólna charakterystyka postępu technicznego, związanego z nim wprost paradygmatu technologicznego, ukazuje dosyć wyraźnie jego granice, znaczone przez jednowymiarowość jego logiki czy redukcjonistyczne założenia stosowanej metodologii. Wskazane granice dość jednoznaczne wskazują na jego niewystarczalność w objęciu całej rzeczywistości.

\section{AMBIWALENCJA W OCENIE POSTĘPU TECHNICZNEGO}

Sama technika od dawna przestała być aksjologicznie, etycznie, a nawet światopoglądowo neutralna. W dotychczasowej tradycji filozofii techniki pojawiały się różne koncepcje i ujęcia wartościowania techniki. Formułowane w jej ramach oceny działalności technicznej były i są zróżnicowane. Ogólnie można wyróżnić, obok dwóch skrajnych ocen pozytywnych bądź negatywnych, również stanowisko pośrednie związane z oceną ambiwalentną. Zwolennicy pierwszego stanowiska podkreślają pozytywny aspekt rozwoju techniki, uznając ją za podstawę dobrobytu człowieka i źródło maksymalnego zaspokojenia jego potrzeb. Problemy negatywnych skutków rozwoju techniki są w tym ujęciu marginalizowane, względnie pomijane. Natomiast przedstawiciele drugiego stanowiska podkreślają jedynie negatywne skutki jej rozwoju, wskazując na niebezpieczeństwo totalnej katastrofy nuklearnej czy ekologicznej, które mogą prowadzić do zagłady wszelkiego życia na Ziemi. Ocena postępu technicznego i jego skutków nie jest łatwa i jednoznaczna. Współcześnie w ocenie etycznej pojawiają się coraz częściej opinie, że postęp może prowadzić zarówno do dobra, jak również do zła. Taka dwuznaczność w ocenie jest dostrzegalna chociażby w różnych odpowiedziach na pytanie: czy wszystko, co jest technicznie możliwe, jest również etycznie dozwolone ${ }^{23}$.

${ }^{23}$ Por. D. Palka, K. Stecuła, Postęp technologiczny - dobrodziejstwo czy zagrożenie?, w: Innowacje $w$ zarzadzaniu i inżynierii produkcji, red. R. Knosala, Opole 2018, s. 590-592; A. Bogner, Einführung: Zur Ethisierung der Technik, w: Ethisierung der Technik - Technisierung der Ethik, s. 9-10. 
Ambiwalentna ocena postępu technicznego jest również widoczna w nauczaniu papieży. I tak, Jan Paweł II zwraca uwagę zarówno na pozytywne, jak i negatywne skutki postępu technicznego. Wyrazem pierwszego jest utrata panowania nad własnymi rezultatami pracy, groźba samozniszczenia, czy bytowania w lęku ${ }^{24}$, a szczególnie niebezpieczeństwo uprzedmiotowienia człowieka. Dzieje się tak, gdy podczas „opanowywania - jak pisze papież - przez człowieka świata rzeczy, człowiek gubi istotne wątki swego wśród nich panowania, na różne sposoby podporządkowuje im swoje człowieczeństwo, sam staje się przedmiotem wielorakiej - czasem bezpośrednio nieuchwytnej - manipulacji poprzez całą organizację życia zbiorowego, poprzez system produkcji, poprzez nacisk środków przekazu społecznego"25. Natomiast źródłem pozytywnej oceny jest wkład rozwoju nauki i techniki w rozwój ludzkości, czynienia życia bardziej godnym człowieka, jak również ukazywanie samej wielkości człowieka jako sprawcy i autora postępu ${ }^{26}$. Wyrażane przez papieża ogóle uwagi dotyczące postępu technicznego nie są jednoznaczne. Mogą być jednak uważne jako pewnego rodzaju klucz hermeneutyczny dla rozumienia w ogóle relacji Kościół - cywilizacja naukowo-techniczna.

Podobnie papież Benedykt XVI przystępując do oceny postępu technicznego wskazuje na ich dwuznaczności. $Z$ jednej strony istnieje możliwość skrajnych ocen, gloryfikujących autonomię i samowystarczalność rozwoju technicznego, z drugiej radykalnie podważających jego użyteczność, w przekonaniu, że powoduje jedynie degradację człowieczeństwa. U podstaw takich ocen papież widzi dwie racje: „ideologiczne absolutyzowanie rozwoju technicznego albo tworzenie utopijnej wizji ludzkości”27. Ostatecznie jednak podobnie jako poprzednik, skłania się ku ocenie pośredniej, stwierdzając wprost: „Technika sama w sobie jest ambiwalentna"28. Ocena taka najwyraźniej zostaje sformułowana we wspomnianym już rozdziale pt. Rozwój narodów a technika, gdzie papież przedstawia podstawy jego pozytywnego i negatywnego wartościowania postępu technicznego. W technice dostrzega sprzymierzeńca człowieka

\footnotetext{
${ }^{24} \mathrm{RH}, \mathrm{nr} 15$.

25 Tamże, nr 16.

26 Tamże, nr 15.

$27 \mathrm{CiV}, \mathrm{nr} 14$.

28 Tamże.
} 
w panowaniu nad materialnym wymiarem rzeczywistości. Bóg nie przekazał człowiekowi świata w gotowej postaci. Człowiek ma go dalej rozwijać, przekształcać, by w pewnym sensie kontynuować dzieło. Postęp techniczny jest tu sprzymierzeńcem człowieka w dopełnieniu panowania Boga nad światem ${ }^{29}$. Nie bez znaczenia dla pozytywnej oceny postępu technicznego ma również jego wpływ na poprawę warunków życia społeczeństw. Postęp technologiczny, będący istotnym faktorem rozwoju ekonomicznego, sprzyja przezwyciężaniu problemów społecznych związanych z głodem, brakiem dostępu do świadczeń medycznych czy edukacjii ${ }^{30}$ Sam postęp jawi się jako sprzymierzeniec człowieka w budowaniu lepszego świata i wspieraniu własnego rozwoju osoby ludzkiej ${ }^{31}$. Właściwie wykorzystane osiągnięcia techniki i ukierunkowany rozwój techniczny czynią życie ludzkie na Ziemi bardziej godnym i przyjaznym.

Benedykt XVI zwracając uwagę na pozytywny charakter rozwoju technicznego nie przemilcza również związanych z nim zagrożeń, które wiąże zasadniczo $\mathrm{z}$ absolutyzowaniem technologicznej perspektywy badawczej czy autonomii techniki ${ }^{32}$. Samo ograniczanie poznania jedynie do ram wyznaczanych przez technokratyczny horyzont kulturowy prowadzi do zubożenia rzeczywistości. Takie podejście sprawia, że współcześnie „mentalność technicystyczna - jak stwierdza papież - staje się tak mocna, że dochodzi do utożsamienia prawdy z tym, co możliwe do urzeczywistnienia" ${ }^{33}$. W takiej sytuacji zostaje zakwestionowana możliwości integralnego rozwoju ludzkiego i całościowej wizji rzeczywistości. Dezintegracyjne działania związane $\mathrm{z}$ absolutyzowaniem techniki są współcześnie najbardziej widoczne obszarze bioetyki i aborcji. W obydwu obszarach dochodzi do głosu - zauważa papież - fundamentalne pytanie: czy człowiek jest wytworem samego siebie, czy też zależy on od Boga. Odkrycia naukowe na tym polu oraz możliwości interwencji technicznej wydają się tak bardzo zaawansowane, że skłaniają do wyboru między dwiema kategoriami racjonalności - rozumu otwartego na transcendencję, albo racjonalności

29 Por. tamże, nr 69.

30 Tamże, nr 21.

31 Por. tamże, nr 68.

32 Por. W. Łużyński, Pierwszeństwo etyki przed techniką w świetle encykliki Benedykta XVI Caritas in Veritate, „Colloquia Theologica Ottoniana” 2 (2013), s. 81.

$33 \mathrm{CiV}$, nr 70. 
rozumu zamkniętego w immanencji” ${ }^{34}$. Papież wyraźnie przestrzega przed zamknięciem na wymiar metafizyczny, jak również wszelkimi próbami redukowania sensu i wartości do wymiaru immanentnego.

Ambiwalencja w ocenie osiągnięć technologicznych jest obecna również w nauczaniu papieża Franciszka. W encyklice Laudato si', przywołując pozytywne oceny postępu technicznego swoich poprzedników, akcentuje wkład technologii zwłaszcza w dziedzinie medycyny, inżynierii i komunikacji ${ }^{35}$. Właściwie ukierunkowanemu rozwojowi technicznemu papież zdaje się przypisywać nie tylko wymierne korzyści, ale wręcz pewne metafizyczne funkcje, które wyrażają się w otwieraniu człowieka na piękno - „w ten sposób pragnieniu piękna twórcy techniki, w tym, kto podziwia owo piękno, dokonuje się przeskok ku jakiejś pełni właściwej człowiekowi”36. Mimo tych wzniosłych słów o wkładzie postępu technicznego w rozwój ludzkości i to nie tylko w wymiarze materialnym, Franciszek nie uważa technologii za bezwarunkowe błogosławieństwo. Obok wielu wymiernych korzyści ze stosowania nowych technologii, papież wskazuje również na zagrożenia związane z wykorzystywaniem technologii do panowania jednych społeczeństw nad drugimi, czy wręcz zagłady, jak miało to miejsce $z$ wykorzystaniem bomby atomowej ${ }^{37}$. Dlatego w krytyce dominującego pojęcia postępu wzywa do sprzeciwu wobec ekspansji paradygmatu technokratycznego ${ }^{38}$.

Ambiwalentna ocena postępu technicznego nie jest finalnym etapem papieskiej refleksji nad tym zjawiskiem czy też swoistym znakiem czasu. W analizowanych dokumentach każdy z papieży zdaje się również formułować pewne konkretne postulaty co do kształtu nowej idei postępu technicznego otwartej na integralną wizję rzeczywistości.

34 Tamże, nr 153.

35 LS, nr 102.

${ }^{36}$ Tamże, nr 103; por. A. Ganowicz-Bączyk, Wątki ekoetyczne w encyklice Laudato si' papieża Franciszka, w: Kościół i nauka w obliczu ekologicznych wyzwań, red. J. Poznański, S. Jaromi, Kraków 2016, s. 208-209.

37 Por. LS, nr 104.

38 LS, nr 111. 


\section{POSTULAT INTEGRALNEGO UJĘCIA RZECZYWISTOŚCl}

Na wstępie tego podsumowującego etapu rozważań warto podkreślić, iż na płaszczyźnie metodologicznej nie ma sprzeczności pomiędzy wiarą chrześcijańską a postępem technologicznym. Chrześcijaństwo nie zakłada - jak stwierdza Benedykt XVI - że istnieje „nieunikniony konflikt między wiarą nadprzyrodzoną a postępem naukowym. [...] nie ma żadnej sprzeczności między Bożą Opatrznością a działalnością człowieka ${ }^{39}$. Do formułowania postulatu integralnego ujmowania rzeczywistości zachęca nie tylko brak sprzeczności, ale również dostrzegane dziś coraz wyraźniej powiązania różnych aspektów rzeczywistości. „Wszystko na świecie czytamy we wprowadzeniu do encykliki Laudato si - jest ściśle ze sobą powiązane, krytyka nowego paradygmatu i form władzy, które wywodzą się z technologii, zachęta do poszukiwania innych sposobów rozumienia ekonomii i postępu"40. Zwrócenie uwagi na kompleksowe powiązania zachodzące $\mathrm{w}$ rzeczywistości i potrzebę rozwijania nowego stylu życia, stanowi wyraźne wyzwanie do integralnego ujmowania rzeczywistości. Tylko taki sposób podejścia do rzeczywistości stwarza szansę scalenia różnych jej wymiarów i przezwyciężenia kryzysu „utraty sensu całości, powiązań istniejących między rzeczami, szerokiej perspektywy, sensu, który staje się bez znaczenia"41.

Właściwa technologii specjalizacja powoduje, że wiedza do jakiej dochodzi człowiek jest fragmentaryczna i może stać się „formą ignorancji, jeśli nie łączy się z szerszą wizją rzeczywistości”"2. Tego typu wiedza nie daje możliwości rozwiązania złożonych problemów ludzkości, zwłaszcza tych dotyczących kwestii ekologicznych czy społecznych. Jednowymiarowość postępu technicznego nie obejmuje całości rzeczywistości. Taką świadomość prezentują wszyscy trzej papieże postulując jednoznacznie dopełnienie technicznie ukierunkowanej perspektywy badawczej o wymiar filozoficzno-teologiczny istotny dla integralnego ujęcia rzeczywistości: Jan Paweł II w nauczaniu o cywilizacji miłości domaga się pierwszeństwa etyki

\footnotetext{
39 Benedykt XVI, Boża Opatrzność a działalność człowieka.

${ }^{40}$ LS, nr 16.

41 Tamże, nr 110.

42 Tamże, nr 138.
} 
przed techniką ${ }^{43}$; Benedykt XVI wzywa do większej korelacji między rozumem i wiarą, która może jedynie uchronić człowieka przed racjonalnością rozumu technicznego zamkniętego $\mathrm{w}$ immanencji ${ }^{44}$; Franciszek domaga się wypracowania takiej idei rozwoju technologicznego, który nie wyraża się tylko przez liczbowe efekty produkcji i materialne mierniki wydajności, ale sprzyja podnoszeniu jakości życia, tworzeniu lepiej zintegrowanego świata ${ }^{45}$. W skazania te wydają się pomoce w wypracowaniu pewnej integralnej wizji rzeczywistości. Należy zauważyć, że zgłaszane przez papieży sugestie nie zawierają jedynie teoretycznych uwag na temat interakcji pomiędzy rozumem technicznym a rozumem otwartym na transcendencję, ale dotyczą również praktycznych działań inspirowanych objawieniem chrześcijańskim, zmierzając do wypracowania nowej idei postępu technicznego zharmonizowanej z całościowym ujęciem rzeczywistości.

Jakie praktyczne działania czy postawy łączą papieże z postulatem integralnego ujmowania rzeczywistości? Wydaje się, że najpierw chodzi o krytyczne podejście do redukcjonistycznych tendencji postępu technicznego, które wyraża się w ukazywaniu niebezpieczeństw związanych z zawężaniem badań jedynie do kwantytatywnych i formalnych aspektów rzeczywistości. Ujmowanie rzeczywistości tylko w kategoriach dla rozumu technicznego powoduje alienację człowieka $\mathrm{z}$ wszelkich transcendentalnych jakości sensu oraz jego redukcję więzi międzyludzkich do sformalizowanych związków. Postawa krytyczna wyraża się również $\mathrm{w}$ demaskowaniu zagrożeń związanych $\mathrm{z}$ deformacją sensu i perspektyw życia ludzkiego, u podstaw których znajduje się zacieśnianie racjonalności do wąsko pojętej nauki, gdzie głównym kryterium działania staje się kryterium pragmatyczne. Chodzi tu o sprzeciw wobec wszelkich prób absolutyzacji nauki i złączonej z nią techniki czy technizacji całej kultury. Wyrażana przez papieży krytyczna postawa wobec jednowymiarowości postępu technicznego nie oznacza kwestionowania postępu technicznego jako takiego, a jedynie domaga się jasnego uznania jego granic w obszarze poznania rzeczywistości i możliwości zaspokajania ludzkich potrzeb ${ }^{46}$.

\footnotetext{
${ }^{43}$ Por. RH, nr 16.

${ }^{44}$ Por. CiV, nr 56, 74.

45 Por. LS, nr 194.

${ }^{46}$ Por. CiV, nr 74, 77; LS, nr 107, 109.
} 
Niebezpieczeństwo „metodycznego” zubożenia rzeczywistości poprzez zawężenie się tylko do możliwości postępu technicznego może zostać przezwyciężone jedynie przez dialog z innymi dyscyplinami nauki. „Człowiek nie może - naucza Benedykt XVI - pokładać w nauce i technice tak absolutnego i bezwarunkowego zaufania, żeby uwierzyć, że postęp naukowy i techniczny jest w stanie wszystko wyjaśnić i całkowicie zaspokoić wszelkie jego potrzeby egzystencjalne i duchowe" ${ }^{\text {"47 }}$. Dlatego postulat integralnego ujęcia rzeczywistości charakteryzuje również wezwanie otwarcia techniki na dialog z filozofią i teologią, który prowadziłby do kompleksowych odpowiedzi ${ }^{48}$. Dialog taki jawi się jako konieczny warunek $\mathrm{w}$ realizacji nowej idei postępu technologicznego uwzględniającej interdyscyplinarne działania, których celem byłoby pełniejsze zrozumienie prawdy o człowieku, otaczającym go świecie i relacjach zachodzących pomiędzy nimi. Dialog z różnymi dziedzinami nauk humanistycznych daje technice możliwość współuczestnictwa w integralnym ujmowaniu rzeczywistości, jak również służy odkrywaniu wielorakich powiązań różnych wymiarów rzeczywistości ${ }^{49}$. Dialog taki przyczynia się do wypracowania nowego myślenia i działania o charakterze globalnym, uwzględniającym interes przyszłych pokoleń, myślenia będącego uwydatnieniem wszystkich potrzeb i wartości człowieka, również estetycznych, kulturalnych i religijnych. Dialog taki może korzystnie wpływać na współtworzenie nowej kultury obchodzenia się z techniką i jej tworami. Tego typu myślenie może okazać się pomocne w zintegrowaniu wiedzy technicznej i religijnej. Zintegrowanie tych dwóch wymiarów wiedzy jest niezwykle ważne dla konkretnego człowieka, który jako przedstawiciel cywilizacji naukowo-technicznej, bądź też jako uprawiający nauki techniczne i współtworzący postęp techniczny, jest równocześnie powołany do zbawienia.

Dążenie do integralnego ujęcia rzeczywistości nie może pomijać postaw będących wyrazem chrześcijańskiej ortopraksji, takich jak: postawa odpowiedzialności, solidarności czy ascezy. Zwłaszcza w kontekście kryzysu ekologicznego wymienione postawy są przez papieży wyraźnie

${ }^{47}$ Benedykt XVI, Boża Opatrzność a działalność człowieka.

48 LS, nr 60.

49 Por. A. Ganowicz-Bączyk, Wątki ekoetyczne w encyklice Laudato si' papieża Franciszka, s. 207; J. Bremer, Encyklika Laudato si' - ekologia integralna podstawowym elementem katolickiej nauki społecznej, s. 39-40. 
akcentowane. Choć należy zauważyć, że odpowiedzialność za postęp techniczny, wpisana w troskę chrześcijaństwa o dzieło stworzenia, nie jest tylko i wyłącznie domeną Kościoła, jego teologii ${ }^{50}$. Analiza zjawiska kryzysu ekologicznego wskazuje, iż ma on ścisły związek z kryzysem moralnym. Kryzys ten nie posiada jedynie wymiaru przyrodniczego i technicznego. Niewłaściwa działalność człowieka względem środowiska naturalnego ma często swoje źródło w przekonaniach filozoficznych, religijnych, etycznych i ekonomicznych. Dlatego Jan Paweł II domaga się przyjęcia i pogłębienia poczucia odpowiedzialności moralnej, i równocześnie troski o rozwój moralny człowieka proporcjonalny do rozwoju cywilizacyjnego. Kryzys świata wartości moralnych człowieka dostrzegalny w prymacie wartości materialnych nad wartościami osobowymi powoduje nieodpowiedzialną eksploatację świata przyrody ${ }^{51}$. Szczegółowo konkretne negatywne skutki aktywności człowieka w świecie wyzwolonej od kryteriów etycznych omawia papież Franciszek, na przykładzie analizy zjawisk, takich jak: zanieczyszczenie i globalne ocieplenie, brak wody, utrata różnorodności biologicznej, pogarszaniu się jakości życia, czy niesprawiedliwości społecznej ${ }^{52}$. Sytuacja ta zmusza do podjęcia działań, które pozwolą przezwyciężyć zaistniałe skutki oraz uniknąć katastrofy ekologicznej. Obok podejmowanych już inicjatyw na płaszczyźnie prawnej i politycznej, mających chronić przyrodę przed dalszą dewastacją i przyczyniać się do jej regeneracji, ważne wydają się również wszelkie działania, które sprzyjają ochronie przyrody na płaszczyźnie etycznej i moralnej. Człowiek jako istota moralna powinien mieć świadomość odpowiedzialności moralnej za otaczającą go rzeczywistość. Chodzi tu o zachowanie właściwych proporcji między rozwojem cywilizacyjnym ludzkości a rozwojem moralnym ${ }^{53}$. Wprawdzie postęp techniczny prowadzi do wyzwalania się człowieka od ograniczeń fizycznych i poszerza jego horyzont możliwości dokonywania wyborów, ale - jak zauważa Benedykt XVI - „wolność ludzka pozostaje

${ }^{50}$ Por. Ch. Hubig, Technik, w: Lexikon der Wirtschaftsethik, red. G. Enderle i in., Freiburg 1993, s. 1079-1081.

${ }^{51}$ Por. RH, nr 16.

52 Por. LS, nr 17-59.

${ }^{53}$ A. Dylus, Integralna ekologia papieża Franciszka. Perspektywa etyki odpowiedzialności, w: Świat jako wspólny dom. Wokół koncepcji ekologii integralnej w encyklice Laudato si', red. A. Wysocki, Warszawa 2016, s. 126. 
sobą tylko wtedy, gdy na fascynację techniką odpowiada decyzjami będącymi wynikiem odpowiedzialności moralnej" ${ }^{54}$. Benedykt XVI, podobnie jak Jan Paweł II, wiążąc kwestie odpowiedzialności za postęp techniczny z moralną kondycją człowieka, wskazują na potrzebę wychowywania do odpowiedzialności etycznej w posługiwaniu się techniką. W łączeniu tych dwóch kwestii można widzieć praktyczny wkład teologii, kultury chrześcijańskiej $\mathrm{w}$ humanizację techniki w obszarze formacji człowieka. Wydaje się on trudniejszy do realizacji w porównaniu $\mathrm{z}$ wymiarem edukacji człowieka, ale jest to istotny element $\mathrm{w}$ trosce o jego integralny rozwój człowieka.

Postęp techniczny nie tylko wpływa na środowisko naturalne, ale również i na społeczne. $\mathrm{W}$ tym ostatnim $\mathrm{z}$ powodu globalnej niesprawiedliwości ${ }^{55}$ dochodzi do degradacji człowieka i całych społeczeństw. Dlatego postulat integralnego ujmowania rzeczywistości nie może pominąć wartości, które mogą stanowić antidotum wobec problemu niesprawiedliwości społecznej. Wśród nich szczególne miejsce papieże przypisują postawie solidarności. Zasada ta - jak pisze Jan Paweł II -

musi być natchnieniem dla skutecznego poszukiwania właściwych instytucji oraz właściwych mechanizmów. [...] Chodzi również o płaszczyznę szerszego i bardziej bezpośredniego podziału bogactw i władzy nad nimi, aby ludy zapóźnione w rozwoju ekonomicznym mogły nie tylko zaspokoić swe podstawowe potrzeby, ale także stopniowo i skutecznie się rozwijaćs ${ }^{56}$.

Również Benedykt XVI zachęca do solidarnych działań, które sprzyjają łagodzeniu niesprawiedliwości i nierówności społecznych oraz budowania solidarnego społeczeństwa. W rozdziale pt. Wspótpraca rodziny ludzkiej, pisze:

Społeczeństwa technologicznie zaawansowane nie powinny mylić rozwoju technologicznego z rzekomą wyższością kulturową, ale powinny odkryć swoje zapomniane czasem cnoty, dzięki którym mogły rozkwitnąć na przestrzeni dziejów. [...] Wiara chrześcijańska, która się wciela w kultu-

\footnotetext{
$54 \mathrm{CiV}$, nr 70.

55 Por. LS, nr 48-52.

$56 \mathrm{RH}, \mathrm{nr} 16$.
} 
ry i je przerasta, może im pomóc wzrastać w powszechnym braterstwie i solidarności, z korzyścią dla rozwoju wspólnotowego i planetarnego. ${ }^{57}$

Rozwijanie postawy solidarności nie jest zasadniczo możliwe bez budowania ewangelijnej postawy ascezy w stosunku do dóbr postępu technicznego. Chodzi o większą świadomość, zwłaszcza wśród chrześcijan, potrzeby patrzenia na człowieka i świat, jako dzieł Boga.

Technika - jak stwierdza Benedykt XVI - nie jest nigdy tylko techniką. Ukazuje ona człowieka i jego aspiracje do rozwoju, wyraża dążność ludzkiego ducha do stopniowego przezwyciężania pewnych uwarunkowań materialnych. Dlatego technika jest objęta przykazaniem „uprawiania i doglądania ziemi" (por. Rdz 2, 15), którą Bóg powierzył człowiekowi, i trzeba ją tak ukierunkować, aby umacniała owo przymierze między człowiekiem i środowiskiem, które powinno odzwierciedlać stwórczą miłość Bożąa ${ }^{58}$.

Dlatego motywowanie człowieka do troski o dzieło stworzenia dla dobra przyszłych pokoleń powinno odwoływać się nie tylko do racji humanistycznych, ale również do objawienia chrześcijańskiego. Praktyczny wkład teologii, w tym szczególnie teologii duchowości polega tu na uczeniu człowieka ascezy $\mathrm{w}$ korzystaniu $\mathrm{z}$ osiągnięć technicznych ${ }^{59}$ czy wręcz rezygnacji w określonych warunkach z pewnych kosztownych technik medycznych. Praktykowanie takiej postawy jest zawsze praktyczną odpowiedzią w perspektywie antropologii chrześcijańskiej na konkretne negatywne skutki cywilizacji technicznej, takie jak: nadmierna konsumpcja, marnotrawstwo, zanieczyszczanie środowiska, bezmyślność oraz rabunkowa gospodarka surowcami ${ }^{60}$. W celu wypracowania takiej postawy potrzeba, zdaniem Franciszka, ekologicznego nawrócenia ${ }^{61}$. To dzięki takiej formie nawrócenia może ukształtować się postawa ascezy, która konkretnie wyraża się w nawykach oszczędzania, samoograniczania

\footnotetext{
57 CiV, nr 59.

58 Tamże, nr 69.

59 Tamże, nr 56, 76.

${ }^{60}$ Por. LS, nr 21-23, 27-28.

${ }^{61}$ Por. Tamże, nr 216-221.
} 
i stanowi skuteczne ograniczanie skutków wybujałego indywidualizmu, egoizmu, hedonizmu czy konsumpcjonizmu ${ }^{62}$.

Współcześnie istnieje szerokie spektrum reakcji na postęp techniczny, począwszy od stanowisk radykalnie optymistycznych czy wręcz dokonujących jego deifikacji, aż po sceptyczne czy wręcz skrajnie negatywne. Wśród tych ocen jest i głos Kościoła wyrażony w papieskim nauczaniu, który dostrzega jednoznacznie pozytywny wkład postępu technicznego, nowych technologii w rozwój ludzkiej kultury, godnego człowieczeństwa i rozwoju społecznego. Równocześnie jednak nie pomija zagrożeń ze strony techniki, zwłaszcza w sferze problematyki ekologicznej i społecznej. Można powiedzieć, że krytyka Kościoła nie jest wymierzona przeciw technologii jako takiej, ale jedynie przeciw wszelkim niekontrolowanym formom postępu technicznego, czy technologiom, które szkodzą dziełu stworzenia i życiu ludzkiemu. Ta krytyka jest szczególnie widoczna, tam gdzie postęp techniczny wiąże się ze wzrostem władzy, pragnieniem panowania nad coraz większymi obszarami rzeczywistości. Chodzi tu o krytyczne odniesienie do postępu technicznego i związanego z nim paradygmatu technokratycznego, który dziś przesadnie uwzględnia jedynie aspekt wydajności, doraźnych ekonomicznych korzyści i jest wyalienowany od jakiekolwiek odniesień etycznych. Tak ujmowany paradygmat technokratyczny wyraźnie narusza katolicką tradycję interakcji pomiędzy etyką i moralnością chrześcijańską a postępem technicznym. Dlatego zasadnicze przesłanie, prezentowanych papieskich poglądów na temat postępu technicznego, domaga się z konieczności, jego ponownego umieszczenia $\mathrm{w}$ kontekście wzajemnych powiązanych pomiędzy różnymi wymiarami rzeczywistości. Istotą nowej idei postępu technicznego ma być uznanie, że „wszystko jest ze sobą połączone”63. Świadomość istniejących powiązań sprzyja przywracaniu pierwotnej jedności pomiędzy homo faber, homo sapiens i homo religiosus. Budowanie tego rodzaju jedności sprzyja

${ }^{62}$ Por. A. Ganowicz-Bączyk, Wątki ekoetyczne w encyklice Laudato si' papieża Franciszka, s. 208; M. Tatar, Ontyczna duchowość stworzenia w perspektywę Laudato si', w: Świat jako wspólny dom, s. 75-77.

${ }^{63} \mathrm{LS}, \mathrm{nr} 16$. 
również humanizacji postępu technicznego wartościami Chrystusowej Ewangelii i równocześnie budowaniu integralnej wizji rzeczywistości, w której postęp techniczny nie jest jedynym aktorem. To oznacza z perspektywy teologicznej związanie postępu technicznego z etyką i katolicką nauką społeczną.

Nowa idea postępu technicznego nie może pomijać konkretnych implikacji praktycznych wyraźnie formułowanych przez papieży, takich jak: solidarne dzielenie się dobrami (Jan Paweł II), rozwój duchowy (Benedykt XVI), ekologiczne nawrócenie (Franciszek). Ich praktykowanie jawi się jako niezbędne dla urzeczywistnienia się integralnej koncepcji rzeczywistości. Ponadto $\mathrm{w}$ tych jasno formułowanych przez papieży wskazaniach można upatrywać tworzenie systemowych podstaw inspirowanych perspektywą teologiczną. Chodzi o długofalowe działania ukierunkowane na integralne ujęcie rzeczywistości, a nie tylko doraźnie w obliczu klęsk spowodowanych rozwojem technicznym.

Papieskie inspiracje co do nowej idei postępu technicznego stanowią ważny przyczynek w tworzeniu teologii techniki, która dziś bardziej niż w przeszłości jawi się jako imperatyw inspirowany teologią stworzenia i antropologią chrześcijańską. Zmiany klimatyczne, nagromadzona broń jądrowa, niekontrolowany rozwój w zakresie nanotechnologii czy sztucznych inteligencji mogą stanowić w przyszłości realne zagrożenie dla egzystencji człowieka. Stąd jednym z istotnych zadań Kościoła w porządku doczesnym jest troska o dzieło stworzenia i samego człowieka, a czasami wręcz obrona ludzkości przed zagrożeniami, wyzwolonego od jakichkolwiek odniesień zewnętrznych, postępu technicznego.

\section{BIBLIOGRAFIA}

Benedykt XVI, Encyklika Caritas in veritate (2010).

Benedykt XVI, Boża Opatrzność a działalność człowieka. Przemówienie do uczestników sesji plenarnej Papieskiej Akademii Nauk (6.11.2006). https://opoka.org.pl/ biblioteka/W/WP/benedykt_xvi/przemowienia/pan_opatrznosc_06112006.html [dostęp: 10.11.2018].

Bogner A., Einführung: Zur Ethisierung der Technik, w: Ethisierung der Technik - Technisierung der Ethik. Der Ethik-Boom im Lichte der Wissenschafts- und Technikforschung, red. A. Bonger, Baden - Baden 2013, s. 7-25. 
Bremer J., Encyklika Laudato się - ekologia integralna podstawowym elementem katolickiej nauki społecznej, w: Kościół i nauka w obliczu ekologicznych wyzwań, red. J. Poznański, S. Jaromi, Kraków 2016, s. 37-54.

Duda A., Wystapienie podczas otwarcia Szczytu Klimatycznego oraz Szczytu Liderów COP24 (Katowice 3.12.2018) http://www.prezydent.pl/aktualnosci/wypowiedzi-prezydenta-rp/wystapienia/art,589, wystapienie-prezydenta-rp-podczasuroczystego-otwarcia-szczytu-klimatycznego-oraz-szczytu-liderow-cop24.html [dostęp: 6.12.2018].

Dylus A., Integralna ekologia papieża Franciszka. Perspektywa etyki odpowiedzialności, w: Świat jako wspólny dom. Wokót koncepcji ekologii integralnej w encyklice Laudato si', red. A. Wysocki, Warszawa 2016, 109-129.

Franciszek, Encyklika Laudato si' (2015).

Ganowicz-Bączyk A., Wątki ekoetyczne w encyklice Laudato si' papieża Franciszka, w: Kościót i nauka w obliczu ekologicznych wyzwań, red. J. Poznański, S. Jaromi, Kraków 2016, 193-214.

Hubig Ch., Technik, w: Lexikon der Wirtschaftsethik, red. G. Enderle i in., Freiburg 1993, s. 1079-1081.

Irrgang B., Philosophie der Technik, Darmstadt 2008.

Jan Paweł II, Encyklika Redemtor hominis (1978).

Łużyński W., Pierwszeństwo etyki przed technikg w świetle encykliki Benedykta XVI Caritas in Veritate, „Colloquia Theologica Ottoniana” 2 (2013), s. 77-90.

Miller C., Technocracy and Tradition, "Communio. International Catholic Review” 44 (2017) 4, s. 718-746.

Mutschler H.D., Die Gottmaschine. Das Schicksal Gottes im Zeitalter der Technik, Augsburg 1998.

Mutschler H.D., Technik als Religionsersatz, „Scheidewege. Jahresschrift für skeptisches Denken" 28 (1999), s. 42-54.

Nordmann A., Technikphilosophie zur Einführung, Hamburg 2015.

Padgett A., God Versus Technology? Science, secularity, and the Theology of Technology, „Zygon” 3 (2005) 3, s. 577-584.

Palka D., Stecuła K., Postęp technologiczny - dobrodziejstwo czy zagrożenie?, w: Innowacje w zarzadzaniu i inżynierii produkcji. Red. R. Knosala, Opole 2018, s. 587-595.

Schleissing S., Laien, Experten, Propheten: Zur Rolle der Theologen in Technikdiskursen, w: Technik und Lebenswirklichkeit: Philosophische und theologische Deutungen der Technik im Zeitalter der Moderne, red. A.-M. Richter, Ch. Schwarke, Stuttgart 2014, s. 203-216.

Tatar M., Ontyczna duchowość stworzenia w perspektywę Laudato si', w: Świat jako wspólny dom. Wokół koncepcji ekologii integralnej w encyklice Laudato si', red. A. Wysocki, Warszawa 2016, s. 61-82.

Wieland Th., Laudato Si’ praktisch, „Herder Korrespondenz” 11 (2016), s. 47-50. 